\title{
O dilema do carcereiro
}

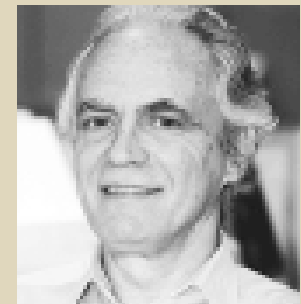

Paulo H. Sandroni FGV-EAESP

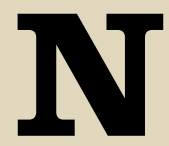

a Teoria dos Jogos, a contradição entre ações individuais racionais e resultad os coletivos desastrosos é ilustrada por uma conhecida alegoria denominada "O Dilema do Prisioneiro".

No Brasil, essa alegoria poderia ser denominada de "O Dilema do Carcereiro". A estória é a seguinte: um perigoso bandido é preso e deve ser mantido incomunicável. A primeira coisa que o poderoso delinqüente faz é ameaçar o carcereiro, sentenciando-o à morte caso não Ihe seja entregue um telefone celular, por meio do qual possa continuar comandando sua quadrilha e cometendo crimes. Diante da ameaça, o carcereiro pensa: "Se cumprir o regulamento e não entregar 0 celular, serei recompensado. Se facilitar o aparelho e a direção do presídio descobrir, serei punido severamente. $M$ as, se não entregar, e algum colega de outro plantão o fizer, o traficante vingativo poderá dar instruções a seus asseclas para que me matem". A diferença entre ser punido pela direção do presídio e ser morto pelos capangas do bandido é tão grande que é mais "racional" para o carcereiro entregar o celular ao bandido, mesmo que isso signifique uma perda coletiva: ele continuará comandando seu bando e provocando crimes.

A atitude mais racional do ponto de vista individual - a preservação da vida - provoca o pior resultado para o bem-estar co- letivo. 0 carcereiro também tem a alternativa de entrar em acordo com seus companheiros para que ninguém ceda às pressões do bandido. Mas ninguém garante que, diante das ameaças, o "elo mais fraco" entre os carcereiros ceda e a "frente única" se rompa, chegando o celular nas mãos do prisioneiro. $\mathrm{Na}$ melhor das hipóteses, reinará, entre os carcereiros, um clima de forte desconfiança.

Em relação à reforma da Previdência, o governo parece ter feito um acordo inicial "entre carcereiros". Mas as pressões vindas de várias áreas sensibilizaram alguns parlamentares da base governista, que, com poderosos ministros, aparentemente cederam, causando grande inquietude nos demais.

$\mathrm{N}$ ão podemos esquecer de que as tentações são feitas para nela cairmos. Do contrário, não teria graça... No início de julho, a linha Maginot de defesa da proposta original de reforma da Previdencia foi vazada. Mas uma operação de retorno à proposta original foi rapidamente montada com a volta do presidente Lula ao Brasil, depois de longa estadia na Europa. É possível que o acordo entre carcereiros seja reconstruído; mas um estrago foi feito na imagem do novo governo, mostrando que não existe a desejável coesão de sua base de sustentação em uma questão tão importante. A desconfiança será a tônica dos próximos lances. 